\title{
EDUCATIONAL SYSTEMS HETEROGENEITY AND THE MODEL OF INTERNATIONAL COOPERATION IN THE FIELD OF HIGHER EDUCATION: EUROPEAN PERSPECTIVE
}

Iana Okhrimenko,

Anastasiia Menshykova,

Lazarski University in Warsaw

\begin{abstract}
The present paper addresses the effectiveness of inter-regional and inter-governmental model of international cooperation in the field of higher education between European and Asian countries from the perspective of European educational system homogeneity. The critical argument pursued in the paper asserts that intra-regional homogeneity is key prerequisite for the inter-regional model of cooperation. By applying clustering algorithm, we prove that European countries feature four distinct educational systems, thus demonstrating a high degree of dissimilarity regarding educational system design. Consequently, we suggest that integration in the field of higher education between the European and Asian countries should take place between economies constituting these regions, not between the regional blocks.
\end{abstract}

Keywords: higher education, international cooperation, educational system, institutions, culture.

\section{Introduction}

The New Silk Road Project is a global infrastructure network that involves many cooperation areas: economics, international relations, security, business, management, sociology, education, etc. The New Silk Road (or One Belt One Road) project could potentially span and integrate major parts of the world across the Euro-Asian continents. International collaboration in the field of higher education is one of the principal pillars of the New Silk Road Project ${ }^{1}$ (Kirby et al., 2018). The present paper aims to explore the possible implications of the New Silk Road for higher education and research cooperation between China and Europe by taking an interdisciplinary approach in collaboration with international partners. It would be argued that integration between the EU and Eastern and Central Asia in terms of education might be efficient, but only as long as the factors affecting the character of the educational system are considered. The study attempts to assess the potential success of international cooperation in higher education in Asian and European countries. The taxonomy of international cooperation in the field of education can be extraordinarily complex. Nevertheless, it is possible to distinguish between three primary levels of international cooperation

\footnotetext{
${ }^{1}$ W. Kirby and M. van der Wende, "The New Silk Road: implications for higher education in China and the West? OUP accepted manuscript", "Cambridge Journal of Regions, Economy and Society", 2018.
} 
in the field of higher education: inter-institutional ${ }^{2}$, inter-governmental ${ }^{3}$, and inter-regional ${ }^{4}$ cooperation. The former takes the form of collaboration between universities located in different regions and countries. Inter-governmental cooperation in the field of higher education can be described as the process of educational systems unification across separated countries. Finally, interregional cooperation can be described as a collaboration between the groups of countries located in different geographic regions and characterized by a high degree of inter-regional heterogeneity and intra-region homogeneity. In other words, integration occurs between the blocks of countries featuring similar cultural values and institutional design. In the context of the present discussion, we analyze two potential forms of international cooperation in the field of higher education between Asian and European countries, namely, inter-governmental and inter-regional cooperation. The key argument pursued in the present paper states that efficient inter-regional collaboration in the field of higher education requires a sufficient degree of intra-regional homogeneity. Alternatively, the countries from the selected region should feature a similar educational system design. Otherwise, the inter-governmental model of cooperation is more effective, implying that international integration in the field of higher education should take place between the economies constituting the regions, not the entire regional blocks. We analyze the issue of regional homogeneity from the perspective of European countries using a clustering algorithm.

The paper is structured as follows. The first section provides a theoretical background for the research, discussing the institutional and cultural environment, the meaning of the educational system, links between institutional environment and educational system, and key institutional and cultural determinants of the educational system design. The second section is devoted to the comparative analysis of educational systems in the Asian and European regions. The third section presents empirical study methodology and results. The last section concludes.

\section{Institutions, cultural environment and optimal educational system design}

\subsection{Institutions}

Institutions can be defined as the scope of rules regulating the entire scope of social life aspects ${ }^{5}$. Under North's framework, the term "institutions" is general enough to involve "both informal constraints (sanctions, taboos, customs, traditions, and codes of conduct), and formal rules (constitutions, laws, property rights)"6. In other words, the institutional environment determines the way in which agents interact and cooperate, serving as the unified "rules of the game"7. The

\footnotetext{
${ }^{2}$ J.S. Antony and T. Nicola, in the book "Successful Global Collaborations in Higher Education Institutions" A. AI-Youbi et al. (Editors), The Tricky Terrain of Global University Partnerships, Springer, 2020.

${ }^{3}$ M. Klemencic, "Intergovernmental regional cooperation in European higher education", 13 "Higher Education Forum", 2016, p. $75-90$.

${ }^{4}$ G. Haug and J. Race, "Interregional Cooperation in Higher Education in Europe", 2 "Journal of Studies in International Education", 1998, p. 3-34.

${ }^{5}$ D. North, "Institutions", 5(1) "The Journal of Economic Perspectives" p. 97-112.

${ }^{6}$ D. North, "Institutions", 5(1) "The Journal of Economic Perspectives" p. 97.

${ }^{7}$ R.W. Scott and J.W. Meyer, in the book " The new institutionalism in organizational analysis" W.W. Powell and P.J. DiMaggio (Editors), The organization of societal sectors: Propositions and early evidence, The University of Chicago Press, 1991.
} 
institutional environment is commonly believed to incorporate social norms and values, thus reflecting the character of the cultural environment ${ }^{8}$. Therefore, it is hard to draw a clear borderline between institutional and cultural environments. However, it would be argued that for the present study's purposes, the ability to distinguish between formal institutions and uncodified arrangements and communication patterns is not crucial. Therefore, in the further discussion, optimal education system design is discussed both from the perspective of explicitly formulated public policy and cultural norms, depending on the context.

\subsection{Educational system}

According to Kitiashvili' ${ }^{9}$, education means the purposeful acquisition of systemic knowledge, skills, and experience accumulated by humankind in various fields of study. Thus, education intends to develop physical, intellectual, and moral skills and is a unique and necessary form of interaction between society and culture. Education is achieved mainly through learning and teaching through an organized, diverse, and unified process of transferring and acquiring knowledge and skills. It would also be argued that the essence and definition of education systems are understood differently in all countries, and that is considered acceptable and healthy because these differences depend on the understanding of all the organs, characteristics, and purposes of education. Here and further, the term "educational system" describes the pattern in which the educational process is organized in a particular country employing formal regulations and as the result of informal social arrangements.

\subsection{The links between institutions, culture, and education}

Cultural differences, starting from the communication style - in speaking and listening - and to the whole attitude of students' behavior, greatly influence the educational system. The atmosphere and students' understanding of the educational institutions differ within Asian and EU countries, creating a big gap between these educational systems. It should be noted that this gap is healthy and has its historical roots and cross-cultural explanations. Starting from primary school, questions like whether it is polite or impolite to ask direct questions of others, whether appropriate or inappropriate to compete openly through talk, have different answers in different countries or, being more specific, cultures. Teachers play an essential role as managers and brokers of the micropolitics of conflict in the classroom ${ }^{10}$. It is transparent that teachers are members of society, so their inner understandings of their role differ from culture to culture, too.

Spillane and Burch ${ }^{11}$ analyze the role of the institutional environment from the perspective of its interaction with instructions, referred to as the core of the teaching process. It should be admitted that the authors deny viewing the institutional environment in education as a unified and monolith construct. Instead, they argue that the institutional environment is differentiated across education

\footnotetext{
${ }^{8}$ A. Alesina and P. Giuliano, "Culture and Institutions", 53(4) "Journal of Economic Literature", 2015, p. 898-944.

${ }^{9}$ Z. Kitiashvili, "For the Definition of the Term Education System in Post Soviet Countries", 2(21), "International Journal of Multilingual Education", 2014, p. 71-76.

${ }^{10}$ F. Erickson, "Culture difference and science education", 18(2) "The Urban Review", 1986, p. 117-124.

11 J.P. Spillan and P. Burch, in the book "The new institutionalism in education", The institutional environment and instructional practice: Changing patterns of guidance and control in public education, SUNY Press, 2006.
} 
stages, reflecting the psychological needs and attitudes of students of different ages. However, it would not violate their logic to assume that although the institutional educational environment is differentiated within a particular society, its components still possess some common features, which can be assessed based on the cross-sectional analysis. Spillane and Burch ${ }^{12}$ argue that the institutional environment, although not constantly shaping the "technical core" of education, determines the way in which knowledge is transmitted to students as well as the entire scope of routines accompanying this process.

To summarize the argument, institutional and cultural environments are argued to determine the character of the educational system, which can be broadly defined as the scope of regulations, norms, and values shaping the educational process. It would be argued, therefore, that successful international cooperation in the field of higher education would require a sufficient degree of cultural and institutional proximity; otherwise, it would be extremely challenging to define a uniform set of principles to govern the educational process.

\subsection{Cultural and institutional determinants of the educational system design}

\subsubsection{Government spending}

Developing the educational system is, in large part, a process of political area. Examples of Central Asian countries are provided here to show how different the situation looks like, considering the historical background. In the 1990s, in the absence of Soviet subsidies, Central Asian countries were forced to reduce the percentage of GDP allocated to education sharply - one of the research indicators explains why the same educational reforms and integrations cannot be equally effective and efficient. In Uzbekistan, this volume of government spending on education decreased by onethird in Tajikistan - four times ${ }^{13}$. Twenty-five years later, education spending in Kyrgyzstan (5.99\% of GDP) and Tajikistan (5.23\% of GDP) is still well below the minimum required threshold for countries with such a low GDP level ${ }^{14}$.

In 2016, in more prosperous countries of the Central Asia region - Kazakhstan (2.98\%) and Turkmenistan (3.05\%) - this indicator remained below OECD (Organisation of Economic Cooperation and Development) standards ${ }^{15}$. Against this background, the countries have also decentralized their budgets from the national to the regional level. This, in turn, led to a significant reduction in funding for schools and universities, in some cases jeopardizing their existence. Budget cuts have also forced the authorities to prioritize higher and secondary education at the expense of lower levels, including preschool education. Between the 2000s and 2010s, less than a quarter of children in Central Asia had access to early childhood care and education, which could not but play

\footnotetext{
12 J.P. Spillan and P. Burch, in the book "The new institutionalism in education", The institutional environment and instructional practice: Changing patterns of guidance and control in public education, SUNY Press, 2006.

${ }^{13}$ Open Society Institute, "Education Development in Kyrgyzstan, Tajikistan and Uzbekistan: Challenges and Ways Forward", available here: https://www.opensocietyfoundations.org/publications/education-development-kyrgyzstan-tajikistan-anduzbekistan [1.s. 26.04.2021].

14 World Bank, "Government expenditure on education, total (\% of GDP)", available here: https://data.worldbank.org/indicator/SE.XPD.TOTL.GD.ZS [1.s.16.03.2021].

15 Open Society Institute, "Education Development in Kyrgyzstan, Tajikistan and Uzbekistan: Challenges and Ways Forward", available here: https://www.opensocietyfoundations.org/publications/education-development-kyrgyzstan-tajikistan-anduzbekistan [1. s. 26.04.2021].
} 
in the long term, affecting the number of people willing to go to higher education now in the 2020s. It is impossible not to mention that the quality of education also suffered - the average salary does not exceed 100 euros $^{16}$. Teachers deal with students and their educational path and have to take on additional responsibilities: maintaining order, communicating with parents, etc. All this led to a flourishing corruption in their ranks and a drop in teacher's and student's levels of motivation ${ }^{17}$ (Children and Youth Services, 2012). In the light of the evidence presented above, it would be argued that the government's role is essential in the case of educational regulations, serving as the determinant of the educational system design.

\subsubsection{Brain drain / Outflow of qualified specialist}

The states of the Central Asian regions face political and socioeconomic realities that affect their education systems. The economies of the countries depend on remittances from abroad by labor migrants. High levels of migration among parents negatively affect the school attendance of their children left behind, especially for less-educated families ${ }^{18}$. The lack of students at the university may lead to the government's decision to reduce the spending and to close it, increasing the unemployment or making teachers and management of universities look for other jobs, decreasing the level of qualified staff in the educational branch. For some people from Central Europe or East Asia, it may sound irrational and meaningless, and this is the point where the cultural environment comes into play, too.

The migration process is a part of globalization, but for those families and persons that come with higher levels of educational and professional qualifications, the possibility of transferring their formal qualifications may be difficult since this form of institutionalized cultural capital is often not recognized in the new society and thus devalued as well ${ }^{19}$. All of this puts migrant families and their offspring in a challenging position in the societal competition. Those, however, who immigrate with a high level of education, integrate faster. At the same time, Central Asian migrants who go to European countries to work for higher salaries and living standards quite often cannot continue doing the exact job they were doing in the home country. A teacher from Kazachstan cannot continue teaching in Germany because of the language barrier or the lack of the required education. In that way, there is an irrational waste of the potential for both countries, Kazachstan and Germany.

\footnotetext{
${ }^{16}$ Open Society Institute, "Education Development in Kyrgyzstan, Tajikistan and Uzbekistan: Challenges and Ways Forward", available here: https://www.opensocietyfoundations.org/publications/education-development-kyrgyzstan-tajikistan-anduzbekistan [1. s. 26.04.2021].

${ }^{17}$ N.N. Habibov, "Does childcare have an impact on the quality of parent-child interaction? Evidence from post-Soviet Kyrgyzstan, Tajikistan, and Uzbekistan", 34(12) "Children and Youth Services Review", p. 2367-2373.

${ }^{18}$ UNDP, "Assessment of the Impact of Migration and Displacement on Local Development in Turkey, Serbia, and the Former Yugoslav republic of Macedonia", available here: file://D:/Downloads/undp-rbec-assessment-impact-displacement-april2017.pdf [1. s. 24.04.2021].

19 J. Heckman, "Policies to Foster Human Capital (with discussion) ", 54(1) "Research in Economics", 2000, p. 3-56.
} 


\subsubsection{Unequal access to education}

Limitation of access to education of children with disabilities has special significance. Children with physical disabilities do not have technical conditions for attending ordinary secondary schools, including lack of special access for persons using wheelchairs, lack of special facilities, etc. As a result, a child may suffer from a lack of regular access to education, communication, and development. Unequal access to education is more common in Central Asian countries than in the $\mathrm{EU}$, creating another social-cultural difference that influences the educational system. In the EU, every student has access to education. The majority of the universities have the facilities to provide every student with the education, considering all the students' features, thinking about their comfortable stay at the university, and providing them with the required needs.

\subsubsection{Gender inequality}

Women today have greater access to higher education and degree-granting institutions than at any other point in history. However, it is still not that common in some countries taken for the analysis of this paper. Gender inequality is a cultural factor that influences the educational system. In some countries of Central Asia, especially ones with the Muslim religion, it is a low prestige among girls to get an education instead of getting married. Another reason is a crusted understanding of gender roles in society, and this understanding has its roots in school education caused by the stable stereotype. According to Olson-Strom and $\mathrm{RaO}^{20}$, for some women from more conservative societies in Asia, the idea of the university is an escape from a restrictive family environment or an unwanted marriage. Many families and communities also prefer gender-segregated education, limiting the options female students have available to them. Moreover, women-only schools and universities often receive less funding and resources than their all-male or co-ed counterparts. This is one way to allocate limited resources, the influence of traditional gender norms, and location interact to prevent women's attainment of higher education ${ }^{21}$.

\section{The comparative analysis of Asian and European educational systems}

\subsection{East Asian educational system}

The educational system of Asian countries consists of two essential pillars: collectivism and strict discipline. The leaders of Asian education are Japan, China, Singapore, and South Korea ${ }^{22}$. In these countries, under the age of 5 , children are allowed to behave practically the way they naturally want, having complete freedom. However, after reaching the age of five, a strict framework is set for pupils, and a period of rigid discipline, overcoming obstacles, and complex study begins. The educational process is based on diligence, organization, perseverance, and concentration of the student. In turn, the student's abilities and interests are not considered in the same way as in the

\footnotetext{
${ }^{20}$ S. Olson-Strom and N. Rao, in the book "Diversity and Inclusion in Global Higher Education" C. Sanger and N. Gleason (Editors), Higher Education for Women in Asia, Palgrave Macmillan, 2020.

${ }^{21}$ S. Olson-Strom and N. Rao, in the book "Diversity and Inclusion in Global Higher Education" C. Sanger and N. Gleason (Editors), Higher Education for Women in Asia, Palgrave Macmillan, 2020.

${ }^{22}$ Academic Ranking of World Universities 2018, available here: http://www.shanghairanking.com/arwu2018.html [1.s. 26.04.2021].
} 
European education system. It is believed that only with the help of the listed qualities can one achieve the peak of success, get a good education, and in the future, a profession. A philosophy that seems strange for the European education system is considered a norm in Asia. However, this strict disciplinary approach is not the same within the whole continent. There are essential differences between the secondary education system and the whole approach. For example, a teacher's authority in Eastern Asia is indisputable; parents do not blame him for their child's failures. Schoolchildren spend most of their time in the classroom, and when it comes to high school, this figure can reach up to 10 hours a day. In Central Asian countries, on the contrary, it is closer to the East European and post-soviet educational approach - teachers have direct communication with the parents, discussing the successes and the mistakes of the children, and the amount spent in school is much lower - 6-7 classes each for 45 minutes, so no more than 6 hours. In Central Asia, it is considered a norm to ask teachers about children's homework until they become students. Furthermore, after ex-school students enter a university, parents still contact the institutions to participate in children's academic lives ${ }^{23}$.

Another example is summer vacations - the time students are free from classes - in China are completely limited to one month, while in EU and Central Asian countries, it is up to two or even three months. The dividing of the academic year is different, too - in Japan, the school year is divided into three parts, each of which finishes with the exams students hardly prepare for. In Central Asian countries, the remains of the Soviet educational system prevail - students have two semesters at school, each of which ends up with the final exams. Also, in the countries of East Asia, the school is 12 classes, the same with Europe, while the countries of Central Asia have just 11 classes. The next part of the article includes more about the educational system in Central Asian countries ${ }^{24}$.

\subsection{Central Asian educational system}

According to the 37th briefing of EUCAM (Europe - Central Asia Monitoring) from September $2019^{25}$, the situation in the educational systems of the Central Asian countries began to deteriorate with the decay of the USSR. In all five countries of the region, to varying degrees, there is a lack of high-quality, effective education. Pervasive corruption and good governance, cultural differences in the mentality that have formed over the years, have contributed to widening the gap between employers' needs and student training. Labour market needs in Central Asia evolved over the past years, and higher education institutions have not always had the necessary resources to adapt curricula at the same pace $^{26}$. All this impedes human development and long-term economic stability.

Funding has become one of the most severe challenges for the newly independent republics. For instance, due to the destruction of the previous system, the education system's resources were

${ }^{23}$ D. McInerney and O. Tan, "What the West Can Learn from the East: Asian Perspectives on the Psychology of Learning and Motivation", Information Age Publishing, 2008.

${ }^{24}$ K. Wilk, "The best educational systems in the world on example of European and Asian countries", 8(3) "Holistica", 2017, p. 103-115.

${ }^{25}$ C. Hill and R. Fernandez-Chung, "Higher Education in the Asian Century: The European legacy and the future of Transnational Education in the ASEAN region (Asia-Europe Education Dialogue) ", Routledge, 2016.

${ }^{26}$ G. Postiglione, "International Cooperation in East Asian Higher Education", Springer, 2020. 
significantly reduced: the salaries of teachers at schools and universities fell sharply, and teaching materials were not updated. In these conditions, almost all Central Asian countries started creating private schools and universities, where tuition fees were encouraged or even obligatory in most cases. Simultaneously, a lack of formal division into commercial and non-commercial educational institutions ultimately led to the spread of corruption in education systems that is a standard procedure there till now ${ }^{27}$.

Taking into consideration the approach to students in Central Asian countries, where a teacher has a strict authority, but where parents and children are in open communication, discussing the mode of studies, question the grades and the assessments, it should be noted that cuts in funding led to the closing of schools and institutions, leaving a teacher with classes of 20-40 students, which led to the reduction in efficiency and motivation of teachers who get a little salary and are responsible for a big amount of classes.

\subsection{European educational system}

European educational systems have two main characteristics: individuality and independence. In European countries, a child is treated as a person who can choose activities and interests. Of course, such upbringing principles prevail not in all European countries, but these principles are cultivated in the EU countries. Therefore, parents do not impose things on children and try to make the entire learning process pleasant for them, in opposition to the Asian educational environment. Also, it should be mentioned that the countries of Central Asia, like Eastern Europe, adopted the theory of upbringing inherent in the USSR, which is also different from what is observed in East Asia and Central Europe. Students are not required to produce outstanding results since this can lead to overload and trauma to the child's psyche - it is interesting to note that in China, all of the above are used in order to temper and educate. In Europe, both parents and teachers strive to support the children and help them overcome the difficulties that have arisen, encouraging emotional openness ${ }^{28}$.

The European education system provides for the development of critical competencies that have a more-than-subject nature. They are a combination of different attitudes, beliefs, and skills that fit a specific context. Core competencies contribute to self-realization, overall personality development, and the formation of active citizenship. In European schools, teachers, in addition to teaching, stake on the education of the student. Thus, the concept of "education" includes preparation not only in scientific terms but also helping the student to develop the abilities of oratory, speaking, working with information, and working in a team. Great attention is also paid to art in a global understanding and knowledge that can broaden student's minds like, for example, $\operatorname{art}^{29}$.

\footnotetext{
${ }^{27}$ D. Rakhmonov and N. Jumaev, "Education in Central Asia", Springer, 2020.

${ }^{28}$ L. Deca, A. Curaj and R. Pricopie, "European Higher Education Area: Challenges for a New Decade", Springer, 2020.

${ }^{29}$ S. Cifuentes and L. Monsalve Lorente, "Comparative study between the educational systems of Spain, UK, France and Germany", "Proceedings of EDULEARN15 Conference 6th-8th July 2015”, Barcelona, Spain.
} 
For instance, in Poland, at the Warsaw School of Economics in Warsaw, at the Faculty of Global Business, Finance and Governance, the student can choose to learn subjects such as Review of American Movies, Social Psychology, Philosophy, Geography and other subjects for general outlook and development. Even in applied science faculties, the student must acquire writing, working with people, communication, and presentation skills.

Also, starting from the middle grades in the European education system, students can independently determine their study plans based on their interests. Universities in various fields offer the development of various research projects on topics of interest to students. Such an approach to learning allows students to develop independence, analytical skills, and a critical habit of mind. In European educational institutions, mechanical memorization of the material is not approved or recommended - many exams are held in the format of the open exams, where it is more important for students to explain in detail how they understand the material than memorizing chapters from textbooks, even in subjects such as economics and finance. During classes, often arise, where everyone can express their opinion, even if it does not coincide with the opinion of classmates. Such lessons are aimed at ensuring that even not completely self-confident students get involved in the process and cultivate leadership and managerial qualities that will be useful in the labor market experience and any interview - even when setting up in a financial institution, where the task of the future employee will be to keep reports. Initiative and entrepreneurial spirit are important personal qualities that are trained in universities. Teachers, as a rule, do not require strict military discipline, but, on the contrary, share their knowledge with students, although, of course, discipline is essential and adherence to rules, especially ethical ones. The form of teaching in the EU is very unobstructed: teachers can communicate with students holding their feet on the table, treating students as colleagues, while fully maintaining subordination and respecting their students. Such a way of interaction may surprise Asian students who come to exchange universities in Europe.

Thus, the main differences between the Asian and European education systems are collectivism in the first place and an individual approach in the second. As a result, it can be assumed that graduates of Eastern Asian institutions are obedient, depending on the collective's opinion, and showing their concern. However, at the same time, it might be difficult for them to join new teams and adapt to constantly changing conditions. Authors' empirical observation suggests that exchange students from Asia to Warsaw universities tend to stick together with their associates, while European exchange students tend to make acquaintances with foreigners - even if they speak a different language. Central Asian educational system still has its roots from the post-soviet educational system that usually was of high standards and discipline, but when stopped being controlled are highly affected by the financial funding and adaptation to the new educational programs. Some programs help Central Asian countries develop education, but it is still significantly affected by the cultural issues discussed in the last part of the paper. At the same time, European graduates are less attached to their compatriots, change their place of residence and work efficiently, have the knowledge that is required at the moment, and which each of them determines and chooses for himself. 


\section{Empirical study methodology and results}

\subsection{Data and data processing}

The main argument pursued in the present paper is that international cooperation in the field of higher education requires a sufficient degree of institutional and cultural proximity. In order to assess the degree of aforementioned proximity between European and Asian countries, we use clustering analysis. The initial dataset included all the countries located in Europe analyzed for the period of 1992-2019. However, the final version of the dataset included 158 observations in the unbalanced panel due to the data availability constraint. Twenty-two indicators describing different dimensions of the institutional and cultural environment related to education were included in the dataset (see the full list in Appendix 1; the data was assessed from the World Bank Education database).

The initial step of the clustering procedure is to define whether the data are clusterable. There are several commonly used techniques to test clusterability. First, we calculate Hopkins statistics to test the dataset against random distribution. Hopkins statistics yields a value slightly below 0.5 (0.47), indicating that the dataset is not clusterable. Nevertheless, the heatmap (see Figure 1) suggests at least three distinguishable clusters.

Figure 1. Visual assessment of clustering tendency

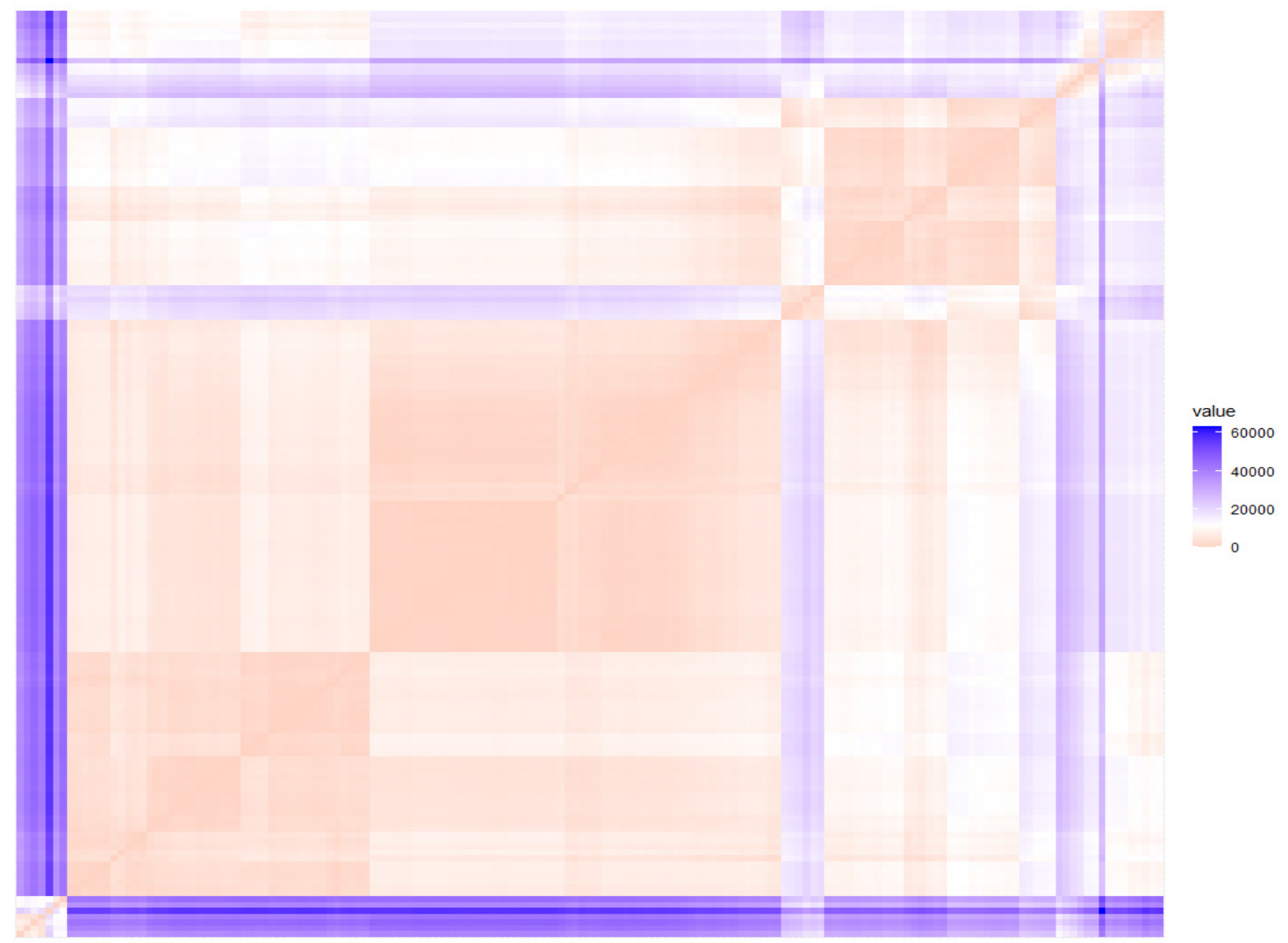


As Adolfsson et al. ${ }^{30}$ (2018) point out, Hopkins statistics is not reliable for detecting clustering tendency in highly-dimensional data. Therefore, we use Hartigan's Dip uni-modality test in order to detect whether Euclidean distances represent a uni-modal or multi-modal distribution. Zero hypotheses of Hartigan's Dip uni-modality test states that data are unimodal, while the alternative hypothesis suggests that data are multi-model (i.e., bi-modal, at least). The p-value of Hartigan's Dip uni-modality test is below 0.01, indicating that Euclidean distances are not uni-modal. Therefore, we can apply the k-means clustering procedure.

In the next step, we standardize the variables and detect the optimal number of clusters using the Elbow rule by analyzing the distribution of the total within sum of squares depending on the number of clusters (see Figure 2). Since the "elbow" of the function corresponds to the third cluster, the optimal number of clusters is four. Therefore, during the k-means clustering procedure, we specify four clusters (the output is presented in Figure 3).

Figure 2. Detecting the optimal number of clusters using the Elbow method

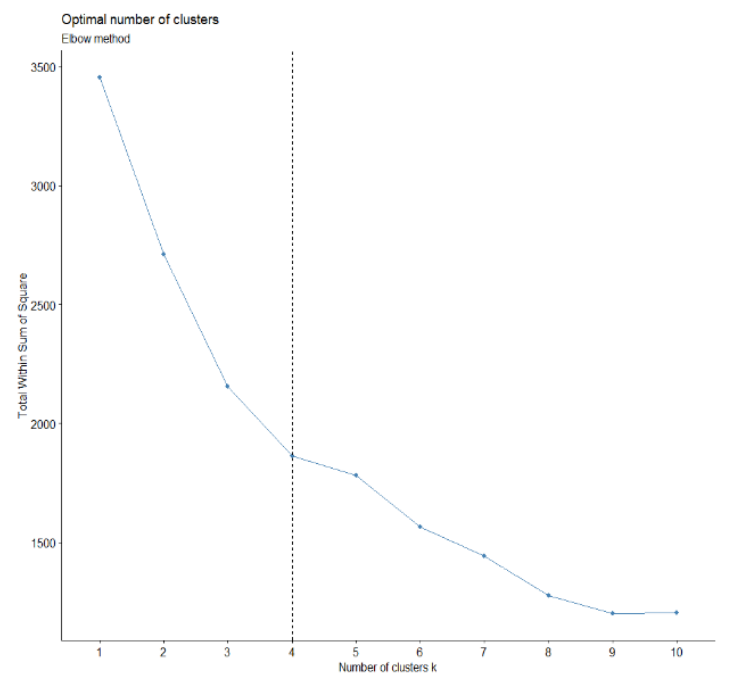

Figure 3. Visualization of clusters

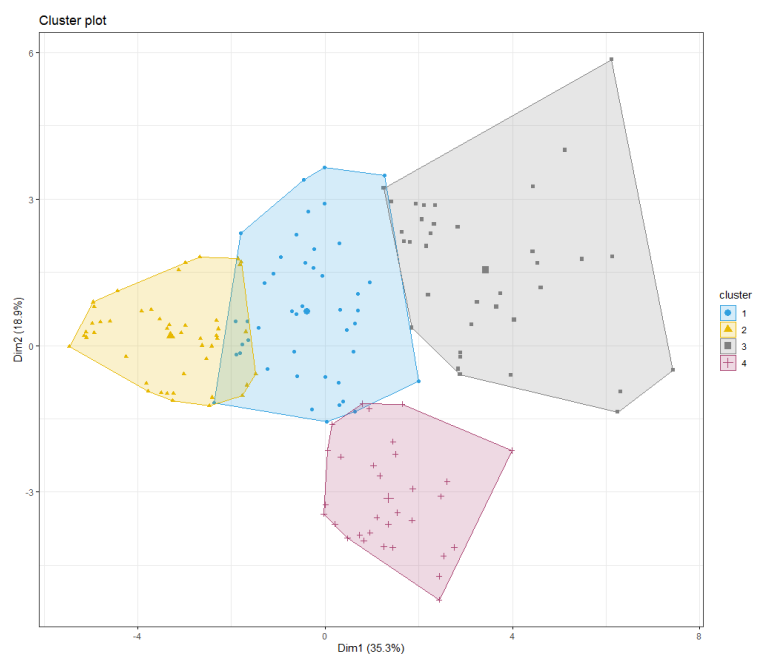

\subsection{Results and discussion}

Figure 4 presents the distribution of the countries across clusters. The first exciting thing to notice is that some countries feature a high degree of consistency over time, while others transfer to different clusters, which, perhaps, reflects essential changes in the field of educational system design.

\footnotetext{
30 A. Adolfsson, A. Ackerman, N.C. and Brownstein, "To Cluster, or Not to Cluster: An Analysis of Clusterability Methods", 2018, available here: https://arxiv.org/pdf/1808.08317.pdf [1.s. 26.04.2021].
} 
Figure 4. Distribution of countries across clusters

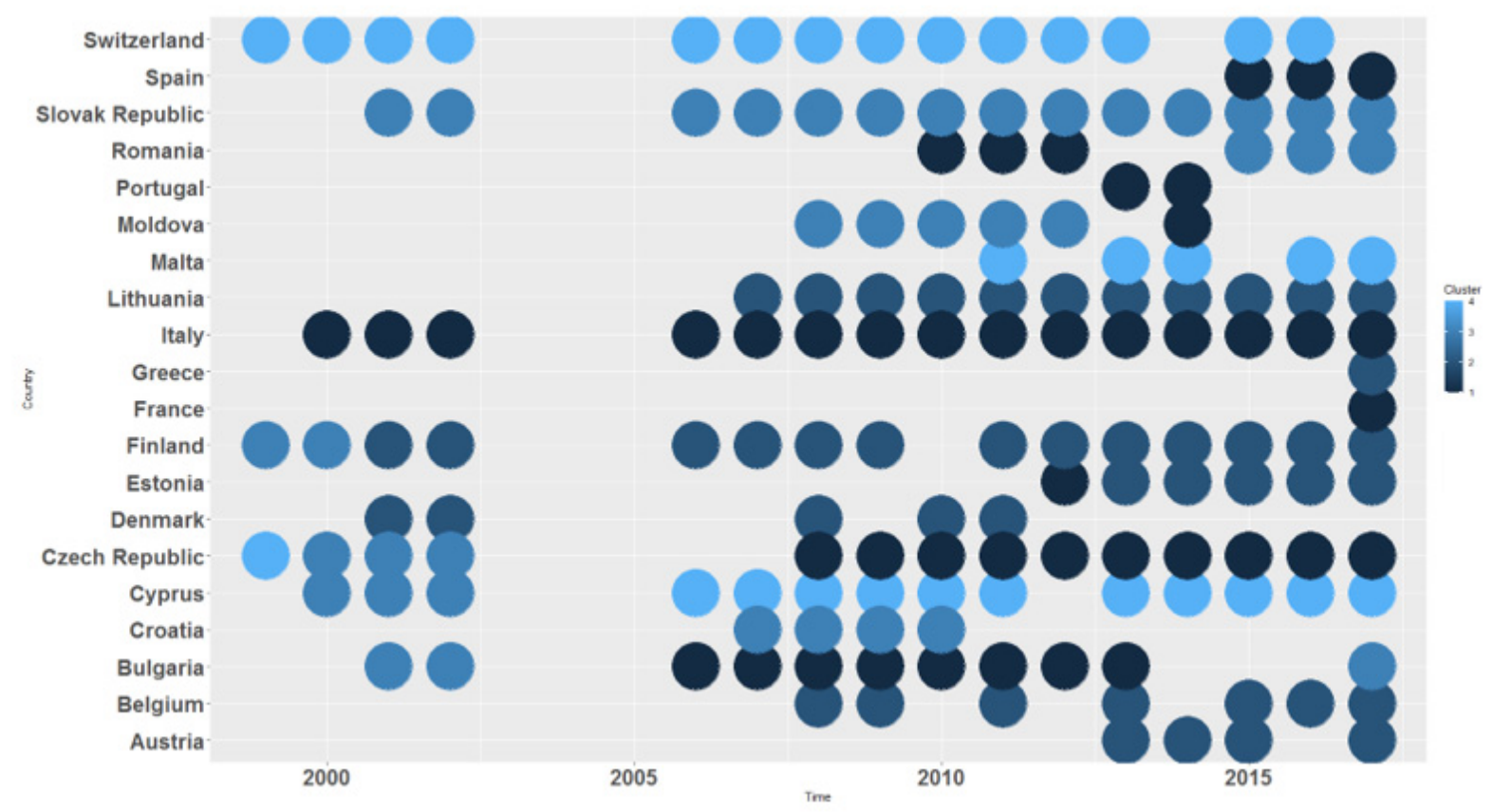

For instance, Switzerland and Malta belong to the fourth cluster during the entire period of analysis. Analogously, Spain, Portugal, and Italy consistently belong to the first cluster. Lithuania, Belgium, and Austria are in the third cluster for the entire period, and the rest of the countries are located in different clusters depending on the year.

The key conclusion that can be derived from the analysis presented above is that European countries are heterogeneous concerning the educational system design. In fact, the uniform European model of education does not exist; instead, there are four different models. In line with the assertion adopted, such heterogeneity implies that the model of inter-regional cooperation between European and Asian countries would be less efficient compared to inter-governmental cooperation. In other words, cooperation on the country level is considered to be a more appropriate solution.

\section{Conclusions}

The present study was devoted to discussing the optimal model of international cooperation in the field of higher education between European and Asian economies. Two models of such cooperation were considered: inter-regional and inter-governmental models. According to the main argument pursued throughout the discussion, inter-regional cooperation can only be effective, if the countries constituting the region demonstrate a sufficient level of homogeneity with respect to educational system design. Otherwise, the countries do not constitute a uniform regional block, thus diminishing the chances for inter-regional collaboration success. In such a case, inter-governmental cooperation, i.e., cooperation 
between economies constituting the regions, would be argued a more appropriate model. The paper analyzed the problem of international cooperation from the European perspective, attempting to determine whether a uniform European educational system exists. Twenty-two variables standing for the various dimensions of cultural and institutional environment relevant to the educational system design were included in the dataset. It was found out that Euclidean distances between the countries are not unimodal, implying set clusterability. Therefore, it was concluded that European states feature four different educational systems; in fact, there is no uniform European model of education. Consequently, in line with the key argument, we conclude that inter-governmental cooperation in higher education between European and Asian countries would be more efficient compared to the inter-regional model. 


\section{Bibliography:}

1. Academic Ranking of World Universities 2018, available here: http://www.shanghairanking.com/arwu2018.html [last verified April 26, 2021];

2. Adolfsson, A., Ackerman, A., and Brownstein, N.C., "To Cluster, or Not to Cluster: An Analysis of Clusterability Methods", 2018, available here: https://arxiv.org/pdf/1808.08317.pdf [last seen 26.04.2021];

3. Alesina, A., and Giuliano, P., "Culture and Institutions", 53(4) "Journal of Economic Literature", 2015;

4. Antony, J.S., Nicola, T., in the book "Successful Global Collaborations in Higher Education Institutions" A. AI-Youbi et al. (Editors), The Tricky Terrain of Global University Partnerships, Springer, 2020;

5. Cifuentes, S., and Monsalve Lorente, L., "Comparative study between the educational systems of Spain, UK, France and Germany”, "Proceedings of EDULEARN15 Conference 6th-8th July 2015”, Barcelona, Spain;

6. Deca, L., Curaj, A., and Pricopie, R., "European Higher Education Area: Challenges for a New Decade", Springer, 2020;

7. Erickson, F., "Culture difference and science education", 18(2) "The Urban Review", 1986;

8. Habibov, N.N. "Does childcare have an impact on the quality of parent-child interaction? Evidence from post-Soviet Kyrgyzstan, Tajikistan, and Uzbekistan", 34(12) "Children and Youth Services Review";

9. Haug, G., and Race, J., "Interregional Cooperation in Higher Education in Europe", 2 "Journal of Studies in International Education";

10. Heckman, J., "Policies to Foster Human Capital (with discussion) ", 54(1) "Research in Economics", 2000;

11. Hill C., and Fernandez-Chung R., "Higher Education in the Asian Century: The European legacy and the future of Transnational Education in the ASEAN region (Asia-Europe Education Dialogue) ", Routledge, 2016;

12. Kirby, W., van der Wende, M., "The New Silk Road: implications for higher education in China and the West? OUP accepted manuscript", "Cambridge Journal of Regions, Economy and Society", 2018;

13. Kitiashvili, Z., "For the Definition of the Term Education System in Post Soviet Countries", 2(21), "International Journal of Multilingual Education", 2014;

14. Klemencic, M., "Intergovernmental regional cooperation in European higher education", 13 "Higher Education Forum", 2016;

15. McInerney, D., and Tan O., "What the West Can Learn from the East: Asian Perspectives on the Psychology of Learning and Motivation", Information Age Publishing, 2008;

16. North, D., "Institutions", 5(1) "The Journal of Economic Perspectives";

17. Olson-Strom, S., and Rao, N., in the book "Diversity and Inclusion in Global Higher Education" C. Sanger and N. Gleason (Editors), Higher Education for Women in Asia, Palgrave Macmillan, 2020; 
18. Open Society Institute, "Education Development in Kyrgyzstan, Tajikistan and Uzbekistan: Challenges and Ways Forward", available here: https://www.opensocietyfoundations.org/publications/educationdevelopment-kyrgyzstan-tajikistan-and-uzbekistan [last seen 26.04.2021];

19. Postiglione, G., "International Cooperation in East Asian Higher Education", Springer, 2020;

20. Rakhmonov, D., and Jumaev, N., "Education in Central Asia", Springer, 2020;

21. Scott, R.W, and Meyer, J.W., in the book "The new institutionalism in organizational analysis" W.W. Powell and P.J. DiMaggio (Editors), The organization of societal sectors: Propositions and early evidence, The University of Chicago Press, 1991;

22. Spillane, J. P., and Burch, P., in the book "The new institutionalism in education", The institutional environment and instructional practice: Changing patterns of guidance and control in public education, SUNY Press, 2006;

23. UNDP, "Assessment of the Impact of Migration and Displacement on Local Development in Turkey, Serbia, and the Former Yugoslav Republic of Macedonia", available here: file://D:/Downloads/undprbec-assessment-impact-displacement-april-2017.pdf [last seen 24.04.2021];

24. Wilk, K., "The best educational systems in the world on example of European and Asian countries", 8(3) "Holistica", 2017;

25. World Bank, "Government expenditure on education, total (\% of GDP)", available here: https://data.worldbank.org/indicator/SE.XPD.TOTL.GD.ZS [last seen 16.03.2021]. 


\section{Appendix 1. List of indicators}

\begin{tabular}{|c|c|c|c|c|}
\hline Code & Indicator Name & Short definition & Source & \\
\hline $\begin{array}{l}\text { UIS.X } \\
\text { GDP.5 } \\
\text { 6.FSG } \\
\text { OV }\end{array}$ & $\begin{array}{l}\text { Government } \\
\text { expenditure on } \\
\text { tertiary education as } \\
\% \text { of GDP (\%) }\end{array}$ & $\begin{array}{l}\text { Total general (local, regional and central) government expenditure on tertiary } \\
\text { education (current, capital, and transfers), expressed as a percentage of GDP. } \\
\text { It includes expenditure funded by transfers from international sources to } \\
\text { government. Divide total government expenditure for a given level of } \\
\text { education (ex. primary, secondary, or all levels combined) by the GDP, and } \\
\text { multiply by 100. A higher percentage of GDP spent on education shows a } \\
\text { higher government priority for education, but also a higher capacity of the } \\
\text { government to raise revenues for public spending, in relation to the size of the } \\
\text { country's economy. When interpreting this indicator however, one should } \\
\text { keep in mind in some countries, the private sector and/or households may } \\
\text { fund a higher proportion of total funding for education, thus making } \\
\text { government expenditure appear lower than in other countries. Limitations: } \\
\text { In some instances data on total public expenditure on education refers only to } \\
\text { the Ministry of Education, excluding other ministries which may also spend a } \\
\text { part of their budget on educational activities. For more information, consult } \\
\text { the UNESCO Institute of Statistics } \\
\text { http://www.uis.unesco.org/Education/ } \quad \text { website: }\end{array}$ & $\begin{array}{l}\text { UNESCO } \\
\text { Statistics }\end{array}$ & Institute for \\
\hline $\begin{array}{l}\text { UIS.X. } \\
\text { USCO } \\
\text { NST.5 } \\
\text { T8.FS } \\
\text { GOV }\end{array}$ & $\begin{array}{l}\text { Government } \\
\text { expenditure on } \\
\text { tertiary education, } \\
\text { constant US\$ } \\
\text { (millions) }\end{array}$ & $\begin{array}{l}\text { Total general (local, regional and central) government expenditure on tertiary } \\
\text { education (current, capital, and transfers) in millions US\$ in constant value } \\
\text { (taking into account inflation). It includes expenditure funded by transfers } \\
\text { from international sources to government. Total government expenditure for } \\
\text { a given level of education (e.g. primary, secondary, or all levels combined) in } \\
\text { national currency is converted to US\$, and where it is expressed in constant } \\
\text { value, uses a GDP deflator to account for inflation. The constant prices base } \\
\text { year is normally three years before the year of the data release. For example, } \\
\text { in the July } 2017 \text { data release, constant US } \$ \text { values are expressed in } 2014 \text { prices. } \\
\text { Limitations: In some instances data on total government expenditure on } \\
\text { education refers only to the Ministry of Education, excluding other ministries } \\
\text { which may also spend a part of their budget on educational activities. For } \\
\text { more information, consult the UNESCO Institute of Statistics website: } \\
\text { http://www.uis.unesco.org/Education/ }\end{array}$ & $\begin{array}{l}\text { UNESCO } \\
\text { Statistics }\end{array}$ & Institute for \\
\hline $\begin{array}{l}\text { UIS.X } \\
\text { UNIT. } \\
\text { GDPC } \\
\text { AP.5T } \\
\text { 8.FSH } \\
\text { H }\end{array}$ & $\begin{array}{l}\text { Initial household } \\
\text { funding per tertiary } \\
\text { student as a } \\
\text { percentage of GDP } \\
\text { per capita }\end{array}$ & $\begin{array}{l}\text { Total payments of households (pupils, students and their families) for } \\
\text { educational institutions (such as for tuition fees, exam and registration fees, } \\
\text { contribution to Parent-Teacher associations or other school funds, and fees } \\
\text { for canteen, boarding and transport) and purchases outside of educational } \\
\text { institutions (such as for uniforms, textbooks, teaching materials, or private } \\
\text { classes). 'Initial funding' means that government transfers to households, such } \\
\text { as scholarships and other financial aid for education, are subtracted from what } \\
\text { is spent by households. Note that in some countries for some education levels, } \\
\text { the value of this indicator may be 0, since on average households may be } \\
\text { receiving as much, or more, in financial aid from the government than what } \\
\text { they are spending on education. Calculation: Total payments of households } \\
\text { (pupils, students and their families) for educational institutions (such as for } \\
\text { tuition fees, exam and registration fees, contribution to Parent-Teacher } \\
\text { associations or other school funds, and fees for canteen, boarding and } \\
\text { transport), plus purchases outside of educational institutions (such as for } \\
\text { uniforms, textbooks, teaching materials, or private classes), minus }\end{array}$ & $\begin{array}{l}\text { UNESCO } \\
\text { Statistics }\end{array}$ & Institute for \\
\hline
\end{tabular}




\begin{tabular}{|c|c|c|c|}
\hline & & $\begin{array}{l}\text { government education transfers to households (such as scholarships or other } \\
\text { education-specific financial aid). When expressed as a share of GDP, this is } \\
\text { then divided by the country's Gross Domestic Product (GDP). Limitations: } \\
\text { Indicators for household expenditure on education should be interpreted with } \\
\text { caution since data comes from household surveys which may not all follow } \\
\text { the same definitions and concepts. These types of surveys are also not carried } \\
\text { out in all countries with regularity, and for some categories (such as pupils in } \\
\text { pre-primary education), the sample sizes may be low. In some cases where } \\
\text { data on government transfers to households (scholarships and other financial } \\
\text { aid) was not available, they could not be subtracted from amounts paid by } \\
\text { households. For more information, consult the UNESCO Institute of Statistics } \\
\text { website: http://www.uis.unesco.org/Education/ }\end{array}$ & \\
\hline $\begin{array}{l}\text { UIS.X } \\
\text { UNIT. } \\
\text { PPPC } \\
\text { ONST. } \\
\text { 5T8.FS } \\
\text { HH }\end{array}$ & $\begin{array}{l}\text { Initial household } \\
\text { funding per tertiary } \\
\text { student, constant } \\
\text { PPP\$ }\end{array}$ & $\begin{array}{l}\text { Total payments of households (pupils, students and their families) for } \\
\text { educational institutions (such as for tuition fees, exam and registration fees, } \\
\text { contribution to Parent-Teacher associations or other school funds, and fees } \\
\text { for canteen, boarding and transport) and purchases outside of educational } \\
\text { institutions (such as for uniforms, textbooks, teaching materials, or private } \\
\text { classes). 'Initial funding' means that government transfers to households, such } \\
\text { as scholarships and other financial aid for education, are subtracted from what } \\
\text { is spent by households. Note that in some countries for some education levels, } \\
\text { the value of this indicator may be 0, since on average households may be } \\
\text { receiving as much, or more, in financial aid from the government than what } \\
\text { they are spending on education. Calculation: Total payments of households } \\
\text { (pupils, students and their families) for educational institutions (such as for } \\
\text { tuition fees, exam and registration fees, contribution to Parent-Teacher } \\
\text { associations or other school funds, and fees for canteen, boarding and } \\
\text { transport), plus purchases outside of educational institutions (such as for } \\
\text { uniforms, textbooks, teaching materials, or private classes), minus } \\
\text { government education transfers to households (such as scholarships or other } \\
\text { education-specific financial aid). Limitations: Indicators for household } \\
\text { expenditure on education should be interpreted with caution since data comes } \\
\text { from household surveys which may not all follow the same definitions and } \\
\text { concepts. These types of surveys are also not carried out in all countries with } \\
\text { regularity, and for some categories (such as pupils in pre-primary education), } \\
\text { the sample sizes may be low. In some cases where data on government } \\
\text { transfers to households (scholarships and other financial aid) was not } \\
\text { available, they could not be subtracted from amounts paid by households. For } \\
\text { more information, consult the UNESCO Institute of Statistics website: } \\
\text { http://www.uis.unesco.org/Education/ }\end{array}$ & $\begin{array}{l}\text { UNESCO Institute for } \\
\text { Statistics }\end{array}$ \\
\hline $\begin{array}{l}\text { UIS.XS } \\
\text { PEND } \\
\text { P.56.F } \\
\text { DPUB. } \\
\text { FNNT } \\
\text { S }\end{array}$ & $\begin{array}{l}\text { Non-teaching staff } \\
\text { compensation as a } \\
\text { percentage of total } \\
\text { expenditure in } \\
\text { tertiary public } \\
\text { institutions (\%) }\end{array}$ & $\begin{array}{l}\text { Non-teacher (e. g. school directors, support staff, administrative staff in local } \\
\text { or central Ministries) compensation expressed as a percentage of direct } \\
\text { expenditure in public educational institutions (instructional and non- } \\
\text { instructional) of the specified level of education. Financial aid to students and } \\
\text { other transfers are excluded from direct expenditure. Staff compensation } \\
\text { includes salaries, contributions by employers for staff retirement programmes, } \\
\text { and other allowances and benefits. To calculate the indicator, divide non- } \\
\text { teacher compensation in public institutions of a given level of education (ex. } \\
\text { primary, secondary, or all levels combined) by total expenditure (current and } \\
\text { capital) in public institutions of the same level of education, and multiply by } \\
\text { 100. Limitations: Although countries responding to the UIS questionnaire on } \\
\text { educational expenditure are required to follow common definitions for staff } \\
\text { compensation, in some cases government budget classifications may differ. It }\end{array}$ & $\begin{array}{ll}\text { UNESCO Institute for } \\
\text { Statistics }\end{array}$ \\
\hline
\end{tabular}




\begin{tabular}{|c|c|c|c|c|}
\hline & & $\begin{array}{l}\text { is also often difficult to separate staff compensation between teachers and } \\
\text { non-teachers, as these are usually grouped together in country's accounting } \\
\text { systems. In general, respondent countries must use estimation methods to } \\
\text { separate teacher and non-teacher staff compensation. For more information, } \\
\text { consult the UNESCO Institute of Statistics website: } \\
\text { http://www.uis.unesco.org/Education/ }\end{array}$ & & \\
\hline $\begin{array}{l}\text { UIS.O } \\
\text { FST.A } \\
\text { GM1.C } \\
\text { P }\end{array}$ & $\begin{array}{l}\text { Out-of-school } \\
\text { children, one year } \\
\text { younger than } \\
\text { official primary } \\
\text { entry age, both sexes } \\
\text { (number) }\end{array}$ & $\begin{array}{l}\text { Number of children one year before primary entry age who are not enrolled } \\
\text { or attending pre-primary education during in a given academic year. For more } \\
\text { information, consult the UNESCO Institute of Statistics website: } \\
\text { http://www.uis.unesco.org/Education/ }\end{array}$ & $\begin{array}{l}\text { UNESCO } \\
\text { Statistics }\end{array}$ & Institute for \\
\hline $\begin{array}{l}\text { UIS.O } \\
\text { FST.A } \\
\text { GM1.F } \\
\text {.CP }\end{array}$ & $\begin{array}{l}\text { Out-of-school } \\
\text { children, one year } \\
\text { younger than } \\
\text { official primary } \\
\text { entry age, female } \\
\text { (number) }\end{array}$ & $\begin{array}{l}\text { Number of children one year before primary entry age who are not enrolled } \\
\text { or attending pre-primary education during in a given academic year. For more } \\
\text { information, consult the UNESCO Institute of Statistics website: } \\
\text { http://www.uis.unesco.org/Education/ }\end{array}$ & $\begin{array}{l}\text { UNESCO } \\
\text { Statistics }\end{array}$ & Institute for \\
\hline $\begin{array}{l}\text { UIS.O } \\
\text { FST.A } \\
\text { GM1. } \\
\text { M.CP }\end{array}$ & $\begin{array}{l}\text { Out-of-school } \\
\text { children, one year } \\
\text { younger than } \\
\text { official primary } \\
\text { entry age, male } \\
\text { (number) }\end{array}$ & $\begin{array}{l}\text { Number of children one year before primary entry age who are not enrolled } \\
\text { or attending pre-primary education during in a given academic year. For more } \\
\text { information, consult the UNESCO Institute of Statistics website: } \\
\text { http://www.uis.unesco.org/Education/ }\end{array}$ & $\begin{array}{l}\text { UNESCO } \\
\text { Statistics }\end{array}$ & Institute for \\
\hline $\begin{array}{l}\text { UIS.R } \\
\text { OFST. } \\
\text { AGM1 } \\
\text {.GPIA. } \\
\text { CP }\end{array}$ & $\begin{array}{l}\text { Out-of-school rate } \\
\text { for children one } \\
\text { year younger than } \\
\text { official age, adjusted } \\
\text { gender parity index } \\
\text { (GPIA) }\end{array}$ & $\begin{array}{l}\text { The Adjusted Gender Parity Index (GPIA) is calculated by dividing the female } \\
\text { value for the indicator by the male value for the indicator. If the resulting } \\
\text { value exceeds } 1 \text {, the ratio is inverted and subtracted from } 2 \text {. The adjusted } \\
\text { gender parity index is symmetrical around } 1 \text { and lies in the range } 0-2 \text {. An } \\
\text { adjusted GPI equal to } 1 \text { indicates parity between females and males. In } \\
\text { general, a value less than } 1 \text { indicates disparity in favor of males and a value } \\
\text { greater than } 1 \text { indicates disparity in favor of females. For more information, } \\
\text { consult the UNESCO Institute for Statistics: http://uis.unesco.org/ }\end{array}$ & $\begin{array}{l}\text { UNESCO } \\
\text { Statistics }\end{array}$ & Institute for \\
\hline $\begin{array}{l}\text { UIS.R } \\
\text { OFST. } \\
\text { AGM1 } \\
\text {.CP }\end{array}$ & $\begin{array}{l}\text { Out-of-school rate } \\
\text { for children one } \\
\text { year younger than } \\
\text { official primary } \\
\text { entrance age, both } \\
\text { sexes (\%) }\end{array}$ & $\begin{array}{l}\text { Proportion of children in the official age range for one year before primary } \\
\text { education who are not enrolled in pre-primary education. To calculate the } \\
\text { indicator, the number of students of the official age for one year before } \\
\text { primary education enrolled in pre-primary education is subtracted from the } \\
\text { total population for one year before primary education. The result is expressed } \\
\text { as a percentage of the population of the official age for the year before primary } \\
\text { education. For more information, consult the UNESCO Institute of Statistics } \\
\text { website: http://www.uis.unesco.org/Education/ }\end{array}$ & $\begin{array}{l}\text { UNESCO } \\
\text { Statistics }\end{array}$ & Institute for \\
\hline $\begin{array}{l}\text { UIS.R } \\
\text { OFST. } \\
\text { AGM1 } \\
\text {.F.CP }\end{array}$ & $\begin{array}{l}\text { Out-of-school rate } \\
\text { for children one } \\
\text { year younger than } \\
\text { official primary } \\
\text { entrance age, female } \\
(\%)\end{array}$ & $\begin{array}{l}\text { Proportion of children in the official age range for one year before primary } \\
\text { education who are not enrolled in pre-primary education. To calculate the } \\
\text { indicator, the number of students of the official age for one year before } \\
\text { primary education enrolled in pre-primary education is subtracted from the } \\
\text { total population for one year before primary education. The result is expressed } \\
\text { as a percentage of the population of the official age for the year before primary } \\
\text { education. For more information, consult the UNESCO Institute of Statistics } \\
\text { website: http://www.uis.unesco.org/Education/ }\end{array}$ & $\begin{array}{l}\text { UNESCO } \\
\text { Statistics }\end{array}$ & Institute for \\
\hline
\end{tabular}




\begin{tabular}{|c|c|c|c|c|}
\hline $\begin{array}{l}\text { UIS.R } \\
\text { OFST. } \\
\text { AGM1 } \\
\text {.M.CP }\end{array}$ & $\begin{array}{l}\text { Out-of-school rate } \\
\text { for children one } \\
\text { year younger than } \\
\text { official primary } \\
\text { entrance age, male } \\
\text { (\%) }\end{array}$ & $\begin{array}{l}\text { Proportion of children in the official age range for one year before primary } \\
\text { education who are not enrolled in pre-primary education. To calculate the } \\
\text { indicator, the number of students of the official age for one year before } \\
\text { primary education enrolled in pre-primary education is subtracted from the } \\
\text { total population for one year before primary education. The result is expressed } \\
\text { as a percentage of the population of the official age for the year before primary } \\
\text { education. For more information, consult the UNESCO Institute of Statistics } \\
\text { website: http://www.uis.unesco.org/Education/ }\end{array}$ & $\begin{array}{l}\text { UNESCO } \\
\text { Statistics }\end{array}$ & Institute \\
\hline $\begin{array}{l}\text { UIS.SL } \\
\text { E.02 }\end{array}$ & $\begin{array}{l}\text { School life } \\
\text { expectancy, pre- } \\
\text { primary, both sexes } \\
\text { (years) }\end{array}$ & $\begin{array}{l}\text { Number of years a person of school entrance age can expect to spend within } \\
\text { the specified level of education. For a child of a certain age a, the school life } \\
\text { expectancy is calculated as the sum of the age specific enrolment rates for the } \\
\text { levels of education specified. The part of the enrolment that is not distributed } \\
\text { by age is divided by the school-age population for the level of education they } \\
\text { are enrolled in, and multiplied by the duration of that level of education. The } \\
\text { result is then added to the sum of the age-specific enrolment rates. A relatively } \\
\text { high SLE indicates greater probability for children to spend more years in } \\
\text { education and higher overall retention within the education system. It must } \\
\text { be noted that the expected number of years does not necessarily coincide with } \\
\text { the expected number of grades of education completed, because of repetition. } \\
\text { Since school life expectancy is an average based on participation in different } \\
\text { levels of education, the expected number of years of schooling may be pulled } \\
\text { down by the magnitude of children who never go to school. Those children } \\
\text { who are in school may benefit from many more years of education than the } \\
\text { average. }\end{array}$ & $\begin{array}{l}\text { UNESCO } \\
\text { Statistics }\end{array}$ & Institute \\
\hline $\begin{array}{l}\text { UIS.SL } \\
\text { E.02. F }\end{array}$ & $\begin{array}{lr}\begin{array}{l}\text { School } \\
\text { expectancy, }\end{array} & \begin{array}{r}\text { life } \\
\text { pre- }\end{array} \\
\text { primary, } & \text { female } \\
\text { (years) } & \end{array}$ & $\begin{array}{l}\text { Number of years a person of school entrance age can expect to spend within } \\
\text { the specified level of education. For a child of a certain age a, the school life } \\
\text { expectancy is calculated as the sum of the age specific enrolment rates for the } \\
\text { levels of education specified. The part of the enrolment that is not distributed } \\
\text { by age is divided by the school-age population for the level of education they } \\
\text { are enrolled in, and multiplied by the duration of that level of education. The } \\
\text { result is then added to the sum of the age-specific enrolment rates. A relatively } \\
\text { high SLE indicates greater probability for children to spend more years in } \\
\text { education and higher overall retention within the education system. It must } \\
\text { be noted that the expected number of years does not necessarily coincide with } \\
\text { the expected number of grades of education completed, because of repetition. } \\
\text { Since school life expectancy is an average based on participation in different } \\
\text { levels of education, the expected number of years of schooling may be pulled } \\
\text { down by the magnitude of children who never go to school. Those children } \\
\text { who are in school may benefit from many more years of education than the } \\
\text { average. }\end{array}$ & $\begin{array}{l}\text { UNESCO } \\
\text { Statistics }\end{array}$ & Institute for \\
\hline $\begin{array}{l}\text { UIS.SL } \\
\text { E.02.G } \\
\text { PI }\end{array}$ & $\begin{array}{lr}\begin{array}{l}\text { School life } \\
\text { expectancy, }\end{array} & \begin{array}{l}\text { pre- } \\
\text { primary, } \\
\text { parity index }\end{array} \text { (GPI) }\end{array}$ & $\begin{array}{l}\text { Ratio of female school life expectancy to the male school life expectancy. It is } \\
\text { calculated by dividing the female value for the indicator by the male value for } \\
\text { the indicator. A GPI equal to } 1 \text { indicates parity between females and males. In } \\
\text { general, a value less than } 1 \text { indicates disparity in favor of males and a value } \\
\text { greater than } 1 \text { indicates disparity in favor of females. }\end{array}$ & $\begin{array}{l}\text { UNESCO } \\
\text { Statistics }\end{array}$ & Institute \\
\hline $\begin{array}{l}\text { UIS.SL } \\
\text { E.02.M }\end{array}$ & $\begin{array}{lr}\begin{array}{l}\text { School } \\
\text { expectancy, }\end{array} & \text { life } \\
\text { primary, } & \text { male } \\
\text { (years) } & \end{array}$ & $\begin{array}{l}\text { Number of years a person of school entrance age can expect to spend within } \\
\text { the specified level of education. For a child of a certain age a, the school life } \\
\text { expectancy is calculated as the sum of the age specific enrolment rates for the } \\
\text { levels of education specified. The part of the enrolment that is not distributed } \\
\text { by age is divided by the school-age population for the level of education they } \\
\text { are enrolled in, and multiplied by the duration of that level of education. The }\end{array}$ & $\begin{array}{l}\text { UNESCO } \\
\text { Statistics }\end{array}$ & Institute \\
\hline
\end{tabular}




\begin{tabular}{|c|c|c|c|c|}
\hline & & $\begin{array}{l}\text { result is then added to the sum of the age-specific enrolment rates. A relatively } \\
\text { high SLE indicates greater probability for children to spend more years in } \\
\text { education and higher overall retention within the education system. It must } \\
\text { be noted that the expected number of years does not necessarily coincide with } \\
\text { the expected number of grades of education completed, because of repetition. } \\
\text { Since school life expectancy is an average based on participation in different } \\
\text { levels of education, the expected number of years of schooling may be pulled } \\
\text { down by the magnitude of children who never go to school. Those children } \\
\text { who are in school may benefit from many more years of education than the } \\
\text { average. }\end{array}$ & & \\
\hline $\begin{array}{l}\text { SE.SC } \\
\text { H.LIFE }\end{array}$ & $\begin{array}{l}\text { School life } \\
\text { expectancy, primary } \\
\text { to tertiary, both } \\
\text { sexes (years) }\end{array}$ & & $\begin{array}{l}\text { UNESCO } \\
\text { Statistics }\end{array}$ & Institute for \\
\hline $\begin{array}{l}\text { SE.SC } \\
\text { H.LIFE } \\
\text {.FE }\end{array}$ & $\begin{array}{l}\text { School life } \\
\text { expectancy, primary } \\
\text { to tertiary, female } \\
\text { (years) }\end{array}$ & & $\begin{array}{l}\text { UNESCO } \\
\text { Statistics }\end{array}$ & Institute for \\
\hline $\begin{array}{l}\text { UIS.SL } \\
\text { E.1t6. } \\
\text { GPI }\end{array}$ & \multicolumn{2}{|r|}{ School life expectancy, primary to tertiary, gender parity index (GPI) } & $\begin{array}{l}\text { UNESCO } \\
\text { Statistics }\end{array}$ & Institute for \\
\hline $\begin{array}{l}\text { SE.SC } \\
\text { H.LIFE } \\
\text {.MA }\end{array}$ & $\begin{array}{l}\text { School life } \\
\text { expectancy, primary } \\
\text { to tertiary, male } \\
\text { (years) }\end{array}$ & & $\begin{array}{l}\text { UNESCO } \\
\text { Statistics }\end{array}$ & Institute for \\
\hline $\begin{array}{l}\text { UIS.SL } \\
\text { E.56 }\end{array}$ & $\begin{array}{l}\text { School life } \\
\text { expectancy, tertiary, } \\
\text { both sexes (years) }\end{array}$ & & $\begin{array}{l}\text { UNESCO } \\
\text { Statistics }\end{array}$ & Institute for \\
\hline $\begin{array}{l}\text { UIS.SL } \\
\text { E.56.F }\end{array}$ & $\begin{array}{l}\text { School life } \\
\text { expectancy, tertiary, } \\
\text { female (years) }\end{array}$ & & $\begin{array}{l}\text { UNESCO } \\
\text { Statistics }\end{array}$ & Institute for \\
\hline $\begin{array}{l}\text { UIS.SL } \\
\text { E.56.G } \\
\text { PI }\end{array}$ & $\begin{array}{l}\text { School life } \\
\text { expectancy, tertiary, } \\
\text { gender parity index } \\
(\mathrm{GPI})\end{array}$ & & $\begin{array}{l}\text { UNESCO } \\
\text { Statistics }\end{array}$ & Institute for \\
\hline $\begin{array}{l}\text { UIS.SL } \\
\text { E.56.M }\end{array}$ & $\begin{array}{l}\text { School life } \\
\text { expectancy, tertiary, } \\
\text { male (years) }\end{array}$ & & $\begin{array}{l}\text { UNESCO } \\
\text { Statistics }\end{array}$ & Institute for \\
\hline
\end{tabular}

